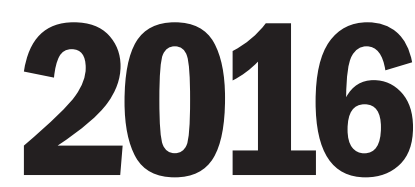

volume 13 | issue 1 an open access journal for architectural research

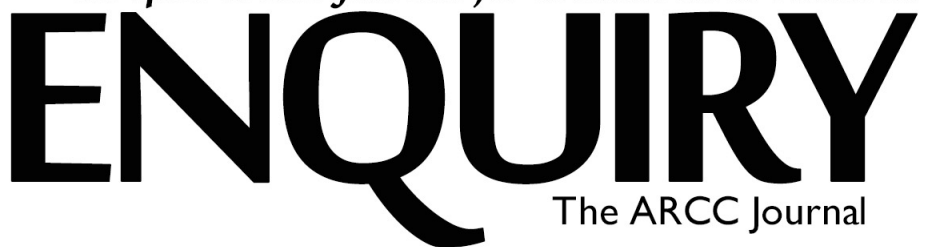

\title{
Sustainable Design and Postindustrial Society: Our Ethical and Aesthetic Crossroads
}

\author{
Leonard R. Bachman
}

\section{ABSTRACT}

Mid-20th century transitions from industrial product society to postindustrial information society have marked profound but now familiar conversions to service economy, knowledge workers, and cybernetic reasoning. Second order, but equally important consequences of this change, involve the transformation from predominantly humanmachine heroics to human-human collaboration. Collectively, these events have revolutionized the bases of production and value across the developed world. Less appreciated however, are the more subtle shifts of postindustrialism and their ultimate epochal transformations of contemporary life. The short list of these more elusive transitions includes local scale isolation to macro and global scale interaction, mechanistic routine to systemic reasoning, static to dynamic assumptions, shorttermism to scenario planning, profit to value motives, hero to team attribution, intuitive to cybernetic decisions, and a move away from rote procedural expertise in favor of reasoned principle, wisdom, and theory. Our historical perspective thus argues for the relevance of postindustrial society in the emergence of a sustainable future, with particular reference to the built environment and to the complex, collaborative, evidence based and cybernetic processes it involves. The difficulty here is that without a vivid and operational understanding of the aesthetic connections and ethical mandates inherent in these more sublime postindustrial events; it is entirely possible that all the best scientific, technical, and political efforts toward sustainability are hampered by

\section{Permissions and copyright}

Authors retain copyright and grant the journal right of first publication with the work simultaneously licensed under a Creative Commons Attribution License that allows others to share the work with an acknowledgement of the work's authorship and initial publication in this journal.

Attribution-NonCommercial-ShareAlike 4.0 International (CC BY-NC-SA 4.0)

You are free to: Share - copy and redistribute the material in any medium or format. Adapt — remix, transform, and build upon the material for any purpose. You may not use the material for commercial purposes. The licensor cannot revoke these freedoms as long as you follow the license terms.

Under the following terms: Attribution - You must give appropriate credit, provide a link to the license, and indicate if changes were made. You may do so in any reasonable manner, but not in any way that suggests the licensor endorses you or your use.

No additional restrictions - You may not apply legal terms or technological measures that legally restrict others from doing anything the license permits.

\section{How to cite:}

Bachman, Leonard. 2016. "Sustainable Design and Postindustrial Society:Our Ethical and Aesthetic Crossroads." Enquiry 13 (1): 30-8. Http://dx.doi.org/10.17831/enq:arcc.v13i2.411 old habits of piecemeal procedures, mechanistic approaches, individual expertise, quick profit, and simplistic short-termism. Postindustrial ethics and aesthetics, on the other hand, offer a new and different apparatus by embracing complexity and dynamic interaction. Within that new aesthetic lies a set of principles and sensitivities towards postindustrial and sustainable era ethics. As such, this present argument attempts to form a cohesive framework contextualizing sustainability, societal trends and nascent evolutions within an aspirational agenda. The underlying theory of this framework describes, explains, and predicts the co-evolution of sustainability and postindustrial events. Finally, the aesthetic basis of the theory is functionally aligned with human cognition. Just as humankind did not quit building with masonry at the end of the Stone Age however, the argument presented here does not demonize the progress of the industrial era that has doubled life expectancy in the last hundred years; nor does it belittle the advent of antibiotics, space travel, telecommunications, rapid transit and the like. It is now necessary however to acknowledge that the pioneer era nature-as-antagonist and industrial era of nature-as-resource have given way to an era of nature-as-model-and-host relation.

\section{INTRODUCTION}

Built environment professionals are currently engaged with two socially significant transformations, both entailing human aspirations toward a progressively better future, and signaling the decline of some practices that were considered to be robust, until recently. Firstly, postindustrial shifts to knowledge work changes our mode of value creation and hence the operating environments in which life's productivity occurs. Secondly, the ideals of sustainable design change the mission of the habitations inside which those environments are situated. Consequently, the outside societal situation is transformed; and the indoor productive condition is constantly adapting. It arguably follows that the built environment interface of outside with inside is necessarily different from previous designs.

At this juncture of historic forces, where postindustrial and sustainable changes intersect, there are already a large number of corresponding and normative realignments in our political, technical, and regulatory frameworks. Moreover, those normative adaptations evolved in the 
usual rote mechanistic ways because the old industrial apparatus of piecemeal incremental response was still the only established fix available. After all, one cannot use the tools of a new paradigm until after the transformation is complete and obsolete methods are functionally replaced with new ones. The old ways have nonetheless served to govern our progressive realization of the new aspirations; both for our means of production and for our built-environment infrastructure. However, because these old ways evolve from the mechanistic attitudes of the fading industrial era, they bring with them some problems from our past habits. As McDonough (1992) puts it, "Human society needs to aspire to an integration of its material, spiritual and ecological elements. Current technologies, processes and means tend to separate these facets rather than connect them". This difficulty with obsolete and piecemeal approaches is, in fact, what Thomas Kuhn (1962) describes in The Structure of Scientific Revolutions as the erosion of existing explanations and the sign of an impending paradigm shift. Corresponding erosion of the old ways in the face of new, more preferred explanations is precisely what this present paper defines in its own terms as a "crossroads" event. Despite any reflex to automatically reject the all too common declaration of a paradigm shift, we should not ignore what Kuhn has so firmly established as a constructive mode of recognizing change.

To situate these two oncoming forces, some characteristics should be described. First, postindustrial and sustainable principles both require systemic coherence and holistic depth of engagement. The cybernetic bases of knowledge production and the complex flows of sustainable building performance both involve looped sets of information, feedback, and adaptive response. Both are complex and wickedly indeterminate problems. Both are clearly concerned with the wholeness and dynamic behavior of systems, be they learning organizations or thermal equilibrium. Both are organisms of deeply interrelated components. From that common origin, the more sublime compounding of sustainable and postindustrial factors begins.

The intersection of postindustrial and sustainable evolution has, at this contemporary crossroads, created several new professional issues specific to their mutual evolution; issues that have yet to transcend the decline of industrial age methodology. In short, the postindustrial and sustainable paradigms fit together and interact in animated ways to bring about new opportunities and new conundrums. The value dimensions of these newly generated issues are also new; they are in a very large part ethical and aesthetic in nature. In articulating these two new dimensions, some philosophical connections between ethical correctness and aesthetic standards come to light. At the intersection of these value constructs and historic vectors, we arrive at some understanding of our contemporary crossroads.

Figure 1 diagrams the crossroads topic of this paper. To explore these two value pairings as a single structure, each of the four factors is first described here as an entity having its own independent characteristics. From there, the intersection of postindustrial and sustainable constructs is laid out as intertwined historical events coming the intersection. Ethics and Aesthetics are then paired in the same way as the oncoming value axis traffic. Finally, the crossroads of all four factors is discussed as a rich, complex, and challenging problem space in which built environment professionals now find themselves.

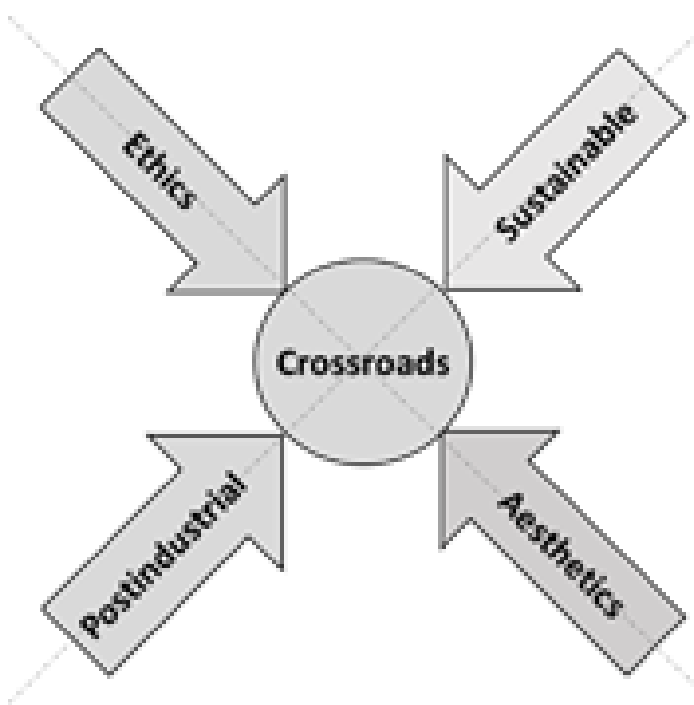

Figure 1. The crossroads of historical and value structure pairs.

\section{POSTINDUSTRIAL SOCIETY AS AN HISTORICAL FORCE}

In postindustrial society where the majority of workers are employed in services, the production of value obviously shifts away from making industrial material goods and toward a hermeneutic cycle of activities in information gathering, organization, inference, proposition, evaluation, feedback, and learning. This abductive and propositional cycle has always been at the root of creativity, innovation, and design work; it is ubiquitous in the best examples of art, science, and architecture. The hermeneutic cycle also exemplifies approaches to indeterminate problems, otherwise known as "wicked problems" or "messes" (Rittel and Webber 1973; Ackoff 1974). Its emergence as the model for everyday activity is however, quite new; so hermeneutic processes require broader understanding before dynamic and interactive modes of productivity are fully accommodated. As Van der Vorst explains, "a change of paradigm implies a change of values guiding the translation of cognition into perception and of perception into behavior." (Van der Vorst 1998, 171)

Industrial attitudes are, by comparison to new third-age modes of production, generally described as mechanistic, linear, reductive, and simplistic (CITATION). Such attitudes are linked to assumptions of straightforward problems where robust solutions can be reached by reasoned application of rote expertise. Table 1 compares some preindustrial, industrial and postindustrial features to highlight the definitional distinctions. Like all rational progress then, the advent of postindustrial thinking has realigned our new behaviors with our new beliefs. Anything less would be a conflict between our actions and our basic belief system, a struggle psychologists call "cognitive dissonance" when encountered at the personal level. So, in the place of linear throughput from raw materials to consumed products to landfill trash, we now see the superior and necessary choice of recycling all spent products into nutrients for other renewed products. Nature is no longer seen as the inexhaustible antagonist and horn-of-plenty harvest as it was in preindustrial pioneering; nor taken as the unlimited source raw 


\begin{tabular}{|c|c|c|c|}
\hline FACTOR & PREINDUSTRIAL & INDUSTRIAL & POSTINDUSTRIAL \\
\hline - Profit Yield & Extraction & Fabrication & Analysis \\
\hline - Economic Sector & Agriculture and mining & Goods manufacture & Services \\
\hline - 1900 Sector & $\begin{array}{l}\text { U.S.: } 110 \text { million in } \\
\text { agriculture workforce }\end{array}$ & $\begin{array}{l}\text { U.S.: } 9 \text { million in } \\
\text { industrial workforce }\end{array}$ & $\begin{array}{l}\text { U.S.: } 9 \text { million in services } \\
\text { workforce }\end{array}$ \\
\hline - 2000 Sector & World: $6 \%$ agricultural GDP & $\begin{array}{l}\text { World: } 31 \% \text { industrial } \\
\text { GDP }\end{array}$ & World: $63 \%$ services GDP \\
\hline 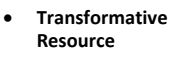 & Wind, water, animals & $\begin{array}{l}\text { Coal, petroleum, } \\
\text { electricity, and nuclear } \\
\text { energy }\end{array}$ & Information \\
\hline Driving Resource & Raw materials & Goods and finance & Understanding \\
\hline Operation & Trial-and-error, experience & Expertise & Theory and principle \\
\hline - Skill & Craft & Know-how & Science and design \\
\hline - Time Orientation & Tradition & Current tends & $\begin{array}{l}\text { Forecasting, backcasting, } \\
\text { and scenario planning }\end{array}$ \\
\hline Organizations & Private companies & Corporations & Global networks \\
\hline Efficiency & Hard work & Fordism and Taylorism & $\begin{array}{l}\text { Operations research, } \\
\text { industrial organizational } \\
\text { psychology }\end{array}$ \\
\hline - Nature & Nature as the context & Nature as resource & Nature as solution \\
\hline - Interaction & People to nature & People to machines & People to people \\
\hline - Cosmology & Natural explanations & $\begin{array}{l}\text { Mechanistic cause and } \\
\text { effect }\end{array}$ & Complex dynamic systems \\
\hline - Ecology & Abundant nature & Pollution, depletion & Sustainable \\
\hline - Morbidity & $\begin{array}{l}\text { Diseases of nature, tooth } \\
\text { infection, childbirth, } \\
\text { accidents, infection }\end{array}$ & $\begin{array}{l}\text { Diseases of industry, } \\
\text { cancer, coronary, } \\
\text { respiratory, obesity, } \\
\text { stress }\end{array}$ & Old age \\
\hline
\end{tabular}

Table 1. Distinctions of industrial and postindustrial society (after Bachman, 2012). Sources: Some portions adapted from Bell, Feb 1976 Physics Today- Welcome to the Postindustrial Society 46-49.

material and end game waste pit of industrial excess. In place of that mechanistic cause-and-effect linkage of local scale impacts, we now understand the macro-comprehensive nature of global interaction. ${ }^{1}$ In place of interchangeable parts and top-down hierarchies, we now work with dynamic systems. Forsaking trend analysis and expertise, we have shifted to scenario planning and backcasting. In short, we have learned to deal with human enterprise in the context of inescapable and irresistible complexity. As a society, we have in fact begun to embrace this complexity in authentic and meaningful ways and these systemic transformations are reflected in today's business world of the early 21st century (Johnson, and Zamenopoulos 2009).

A couple brief examples will illustrate the emerging postindustrial mindset. Overall, the difference is essentially that of interrelated dynamic systems replacing linear static machines. In place of robust expertise toward simplistic and static problems for example, it is necessary to develop adaptable solutions to dynamic situations. Consider how modern production of a product is now linked back to its automated manufacture and market packaging: to design a car,

\footnotetext{
${ }^{1}$ For Immanuel Kant, local and global realities reflect our membership in the noumenal (intelligible) and phenomenal (sensible) worlds. For David Bohm (1980, Wholeness and the implicate order, London; Boston: Routledge \& Kegan Paul) these are the local and non-local aspects of reality. There is also a connection to Karl Popper's Three Worlds perspective of: 1) The world as it is, 2) The personal subjective world, and 3) the shared intersubjective world of constructs (K. Popper. 1978. The Tanner Lectures on Human Values: Three Worlds. University of London. http://tannerlectures.utah.edu/_documents/a-to-z/p/popper80.pdf. Accessed 30 November 2014.). Through Popper, the real, the perceived and the constructed realities of Plato's Cave are referenced. From Plato then we come full circle back to Kant.
}

one must first design the factory that can make it and the robots that would build the product. This same sort of agility is required in the postindustrial business model regarding all phases of commerce. For technology uptake, the transition from stereo vinyl records to cassette tapes, compact disk, digital video disks, and then digital mp3 file formats occurred in a timespan of some 50 years. This rapidly accelerating motion dictates continuous reconsideration of what it means to be in the music media business. Beyond rigid expertise, it was necessary to rely on theory and principle. Instead of training a workforce for rote tasks, it is necessary to develop "knowledge organizations". Instead of repeated cases of new problems, now whole new issue sets come about on a constant basis. These problems are indeterminate, unbounded, and hard to isolate from other interacting factors. They are, in short, the wicked problems and messes that Ackof and Rittel (1960) brought to forefront. Seemingly all such accelerating change evokes Toffler's Future Shock 1970) and Moore's Law of exponential change. ${ }^{2}$

Additionally, decision making in postindustrial production is extensively reliant on cybernetic feedback from analysis performed using computers. For example, most major building codes now require extensive detailed simulation of building energy performance before a building construction permit is issued. In practice, this requirement for embodied intelligence in the building makes it necessary to incorporate energy efficient strategies and features from the very first conceptual design phase. The old linear sequence of design by architect, then size by engineer, and construct by low bidder has given way to terms like "integrated project delivery" and "building information management." In the new context, project teams collaborate closely across the entire span of work and serve to augment and balance each other's thinking process. Even after construction, the processes of "continuous commissioning," continually adapts the operation and maintenance of a facility to its changing uses. "Post-occupancy evaluation then measures how well the actual users perceive the architects' intent and successful realization. True to the norms of information society then, the design is not only programmed around flexibility and adaptability in the planning stages; but is also both verified and validated in use. (Bachman 2009)

As another aspect of the postindustrial built environment, it is important to recognize that the fundamental nature of a building has shifted. Using the office building as an example because it houses the knowledge worker, the corporate client now sees the workplace environment just as the automobile manufacturer sees the factory: as a facility for production. While iconic building image and the quest for status may still drive some aspects of office design, there is much more emphasis on "evidence based design" that follows empirical measures of design outcomes in office workplace productivity, hospital bed stay, or other tangible outcomes. Office churn, employee absenteeism, and corporate investment in human capital are just a few items of note to the office building example. It is sometimes said that this evidence based approach produces an ideal working environment "surrounded by six inches of architecture."

\footnotetext{
2 Moore's Law essentially states that computer power doubles about every 18 months relative to the same cost and size as before... see Gordon E. Moore. (1965). Cramming more components onto integrated circuits. Electronics Magazine. p. 4.
} 
Finally, building structures themselves advance through the same accelerating cybernetic technology as evidenced in the tools used to design them. Building automation has advanced from one-way timers and alarm sensors to two-way communication involving networks of sensors embedded in building hardware. Beyond that, neural network technology has introduced the practical possibility of intelligent buildings that learn about their own performance and can anticipate upcoming demands. Given the increasing number of dynamic building component products like electrochromic glass that goes opaque or clear with a small voltage signal, we will soon work with buildings that even change their own visual appearance and configuration. Such buildings will be smart enough to have an avatar that talks to you directly at your desk via the office intranet. Say "Hi" to the postindustrial building.

\section{SUSTAINABILITY AS AN HISTORICAL EVOLUTION}

"Sustainable development' is the term created to describe a possible approach to environmental problem-solving as an integral element in society (and industry)." Van der Vorst 1998, 173)

Beginning with a relevant redefinition, William McDonough's (1992) generally accepted Hannover credo on sustainability (which goes back to earlier work by the World Commission on Environment and Development) on sustainability is rephrased here to include an ethical and aesthetic component of human aspiration. We can thus redefine sustainability as (italic passages by the author) "The ability of the present generation to meet its needs and aspirations without sacrificing the ability of future generations to meet their own needs and aspirations [sic]"(173). ${ }^{3}$ In modifying McDonough's definition of sustainability with that aspirational component, as his own quote in the Introduction of this paper evokes, the ethical and aesthetic values of sustainability can be integrated in later sections of this paper. For now, the E3 triad of economics, environment, and equity can serve as an outline for discussion.

Economic optimization by energy conservation and renewable energy production is the most obvious technical fix of green buildings in the agenda of sustainable design. But, while energy economy is not without ethical and aesthetic repercussions, environment and equity are more important to those broader social values.

Environment, in this context, refers to the preservation and advancement of natural ecology as a holistic and comprehensive setting in which humans and their built environment dwell. Because it is a shared and fragile setting, there are ethical concerns regarding to what extent the

\footnotetext{
3 This definition can also be traced to "Our Common Future" (1987) World Commission on Environment and Development chaired by Gro Harlem Brundtland. The later report, as related by Van der Vorst, goes on to relate that "The report continues with explaining that Development involves a progressive transformation of economy and society $[19$, p. 43) and clarifies that sustainable development stands for a.. . process of change in which the exploitation of resources, the direction of investments, the orientation of technological development and institutional change are all in harmony and enhance both the current and future potential to meet human needs and aspirations [ 19, p. 46)." For the later, see Van der Vorst (1998), page 173.
}

environment is exploited for individual gain or irreversible decline. As it relates to natural beauty, there are aesthetic concerns regarding its preservation and utilization. Other environmental issues go beyond energy conservation and economics to include site selection, access to public transit, light pollution and trespass, indoor environmental quality, sourcing and transport of construction materials, the embodied energy of materials used, ongoing maintenance and life-cycle considerations, and the eventual end of project life demolition of the building. Extended time scale is particularly important in the environmental agenda of sustainability, particularly in contrast to short-term speculative building for quick profit.

Equity in sustainable design demands a broad social perspective rather than a narrow cultural focus. Consideration is required for the overall well-being of society as impacted by the design choices made, both near to and far from the project, both in present time and on into the future. Who made the building materials and how are they fairly compensated? How does the building design address public good as well as private gain? Beyond utilitarian function, how does the design nourish public well-being? In what ways is the design an emancipatory and liberating expression?

It is appropriate at this point of the argument to also note that sustainability is ultimately an ethical choice of value priorities. The technology exists to produce low energy and "net zero" buildings, especially with the augmentation of on-site renewable energy sources or purchased energy from renewable providers. The decision to minimize the environmental demands of the building design in the first place, then provide remaining needs with renewable technologies is an investment value decision of both economic and ethical dimensions. To weigh sustainability in that balance requires that owners and design team members believe that a high level of performance is a worthwhile goal. It is also fair to say in this regard, that the niche of sustainable design is probably better forgotten as a "different" mode of design by emphasizing its character into the standard expectation of all building design. In that way, sustainability would be much more successful after its separate focus ended. There will always be strong regard for high performance buildings, and attaining the level of environmental autonomy might just be a natural step. The intentional escalation of energy code requirements with each successive iteration of the code is a regulatory symptom of how that value transformation might be encouraged.

\section{ETHICS}

"The rise of professionalism and the related claims for self-regulatory powers, expertise and 'autonomy' of the professions as well as for advocacy of the public interest have never been without problems (Saks 1995). Historically, professionalization processes were inevitably linked with social exclusion and the making of inequality both in the labor market and the wider society." (Kuhlmann 2013, 9).

Turning the conversation from forces of history to aspects of value, we begin with notions of ethical conduct. Professional occupations in the production of our built environment operate within high ethical 
expectations. ${ }^{4}$ The professionalization of architecture and engineering are perhaps especially relevant for reasons of licensure, but all the allied trades share the same contract with society: namely that of access to their occupation in return for a promise to serve public health, safety, and welfare. Architects, therefore, wield their command of a large and difficult body of knowledge in service to society (Snyder 1984). In return, they secure not only a meaningful occupation and financial reward, but also a monopoly on their trade and the opportunity for gratifying recognition.

In trust of this promise of service, built environment professionals are expected to practice a "collectively shared altruistic vision towards the advancement of public good including a high regard for ethics, mores and traditions and a concern for shared well-being." (Bachman 2013) Hill et al. (2013), however, claim there is an ethical dilemma between the realities of the marketplace and the ethical ideals of altruistic design, especially in contrast with the value systems needed to support longterm sustainability. Their critique of social inequity purports that: "The market is conditioned by a general disregard for the public interest... the environment... and an assumption that unbounded growth is a necessary condition... ." (10) This complaint is echoed by Twinn (2013), who notes that "built environment professionals seem to have been driven into a space in which they are expected to apply their skills with little question or reflection about the risks of 'business as usual'." (123) Bordass and Lehman (2013) concur:

\begin{abstract}
"Most authors agree that professionalism has been eroded by short-termism, bureaucracy and outsourcing of technical skills by government. Accountability is replacing trust, reflecting what has been happening in wider society - the unintended consequence of replacing ethics by rules and regulations, and leaving everything else to the invisible hand of the free market... Urgent challenges include dealing with rapid growth in developing countries, diminished resources in developed ones, and sustainability everywhere."
\end{abstract}

The overarching complaint of many observers in this regard relates to the concept of "short-termism." (Bachman 2013) Twinn (2013, 123) notes that despite the "tremendous maturity in building professionals' understanding of sustainability" and the great advances in building technology that enable more sustainable performance, little real progress is being made at the scale of the public sector. Short-termism is blamed for those failures, and not just in the built environment. In the waning era of the industrial age, short-termism is ubiquitous: politicians want to get re-elected, newspapers want to sell copy, journals want subscription, and corporations want to track annual profit. Investment in long-term values and benefits such as sustainability don't often fit that equation. Short term gratification generally rules.

Long term values on the environment and sustainability have, in fact, been codified into ethical professional behavior. The American Institute

\footnotetext{
${ }^{4}$ See the special New Professionalism theme issue of Building Research and Information, B. Bordass and A. Lehman, eds. 41:1, as well as L. Bachman 2013. New Professionalism: the post-industrial context, Building Research \& Information, 41:6. Accessed 18 December 2014 http://dx.doi.org/10.1080/096 13218.2013.804778.
}

of Architects (AIA) Code of Ethics \& Professional Conduct, for example, is divided into broad principle cannons, which are defined by ethical standards, and dictated by rules. Only the rules are mandatory, but most rules evoke specific cannons and standards. And, while not all architects in the United States are members of the AIA, the document is nonetheless instructive. The following are literal excerpts:

1. "Members should maintain and advance their knowledge of the art and science of architecture, respect the body of architectural accomplishment, contribute to its growth, thoughtfully consider the social and environmental impact of their professional activities, and exercise learned and uncompromised professional judgment... 2. Members should respect and help conserve their natural and cultural heritage while striving to improve the environment and the quality of life within it...

3. Members should promote sustainable design and development principles in their professional activities...

4. Members should use sustainable practices within their firms and professional organizations, and they should encourage their clients to do the same."

There is an obvious need to shore up conversations about the built environment professions to address such short-termism and to scaffold up from discourse among the concerned parties. (Bachman 2015) Aside from the market forces that Hill notes however, there are several other issues of professionalism that compound the challenges professionals are facing. To date however, the studies of professionalism in the built environment have not led to widespread action. Commentary both from within their respective organizations and from the social science research available have not yet been sufficient to the task (Bachman 2015). Without attempting such a study within the bounds of this paper's already large scope, here is a short list of some of the compounding threats beyond market demands and short-termism:

1. Corporatism managerialism and the attribution of authorshipIn the United States today, about 30\% of all architects work for the 175 firms that employ more than 100 architects each. Firms between 50 and 99 architects account for another 20\% of US architects. While teamwork is a positive factor of this situation, the dilution of personal responsibility toward the environment and the corresponding erosion of personal pride in authorship both point toward ethical issues of accountability;

2. Protection of professional domain from encroachment-As more and more specialties enter the market for built environment services, competition for pieces of the same pie increases; and the value propositions are changed. There have been about 100,000 licensed architects in the United States for some 20 years. The total number doesn't change much, but the percentage of architects in minor subordinate roles appears to be growing; (Stevens 2002) 3. Value proposition-What is the value of design; who needs it; and can it be done without?

\footnotetext{
${ }^{5}$ See http://www.aia.org/aiaucmp/groups/aia/documents/pdf/aiap074122.pdf .
} 
4. Public access to professional knowledge base-The knowledgepower nexus of the designer can be eroded by the now ubiquitous access to professional knowledge available in the internet search information age.

\section{AESTHETICS}

"The ontological function of the beautiful is to bridge the chasm between the ideal and the real" (Gadamer 1986)

"Aesthetics conveys the interdependence of our understanding and our appreciation" (Scruton 1979)

"...nature does everything either because it is (conditionally) necessary or because it is better." (Aristotle)

Although aesthetics is, by definition, concerned with the philosophy and psychology of human appreciation, it is not always clear what is necessary to attain such appreciation. To say that aesthetics is the appreciation of beauty for example, still leaves out the distinctions of natural, artistic, moral, and intellectual beauty. It is also true that different cultures will have a wide range of varying appreciations for different modes of beauty and will relate to different aesthetic value bases. Architecture is thus well situated to evoke multiple and overlapping modes. Since architecture is our place in nature for example, natural beauty can be the context of design and because buildings and landscapes are artifacts of human intention, their artistic beauty is an inherent expectation. Furthermore, professional ethics require altruistic intent, service to society, and a high level of good behavior; so moral beauty is also in the scope. Finally, the built environment is expected to embody human intelligence in ways that translate ideal aspirations about space into concrete reality of place; so intellectual beauty is also a point of departure.

Given those multiple entry points, aesthetics is a commonplace and universal element of design discourse; but also a commonly misunderstood one. The everyday perception of aesthetic value as a synonym for beauty has the unfortunate limitation of reducing both aesthetics and beauty to personal, subjective, and highly specious argument. It is more useful and accurate to describe aesthetics as a public issue, after Gadamer and Scruton, as a connective function. That connection entails the cognitive link between, on one hand, our immediate and sublime encounter with the object or event and, on the other hand, our insight as to its fit and purpose. From Gadamer's (1986) theory of ideal and real there is thus a direct link to immediate phenomena and noumenal foresight; a connection that can be validated in polite discourse. Scruton's (1979) appreciation and understanding also forge such a link of the ideal and the real: between phenomenal perception and the noumenal understanding. Using the work of neuroscientist F. Scott Kelso, this ideal/real, immediate/foresightful, and appreciation/understanding dynamic is manifested in the two hemispheres of the human brain (Kelso 1999; Bachman 2012). Here the dynamic of human cognition becomes a design thinking model for aesthetic operations: the connection between affect (right-brain, sublime, immediate...) and effect (left-brain, intelligent, foresight...) combine to make a complex and mindful whole. That is how we can understand the brain organ to become the animated mind, and how we can similarly resolve the design connection between ideal pursuits and realistic constraints. This marriage of left-brain intelligent foresight with right-brain sublime immediacy thus connects our appreciation and our understanding.

From the viewpoint of sustainability this connection can be modeled back to the unity of our real needs and our ideal aspirations. The brain/mind distinction, as neuroscience now claims it to operate, applies directly to the built environment as the difference between a functional component and an animated organism. Including human aspiration in the definition of sustainability is thus both an aesthetic and an emancipatory ethical mandate. The aspirational component of sustainable design not only assures the fit of design and purpose, but does so without relinquishing the human urge to experience the sublime. It is aesthetics, ethics, and sustainability at the crossroads.

\section{POSTINDUSTRIAL AND SUSTAINABLE: ON THE AXIS OF HISTORY}

Having so far described the four aspects of the crossroads issues, the conversation is now directed at connecting the two pairs of historical and value aspects. Firstly, congruent aspects of postindustrial and sustainable evolutions have placed those two historical forces on the same road and can be described as converging circumstances. Both emerged in the post-World War II era and by the 1960s were well documented as architectural issues. Overlap can even be seen in works such as William Pena's (1969) Problem Seeking, one of the earliest and now seminal works on architectural programming as a means of dealing with design complexity. From our contemporary situation to about 45 years later, it is hard to realize that the process of codifying information about a design project had never been systematized before then. Until Peña, Sanhoff, and a fledgling other few thinkers, design had always been thought of as problem solving. Beyond its primitive roots in the writing of Renaissance design competitions for major projects, the advent of systematized programming only emerged when the complexity of design problem space became more critical and complicated. Also note the rough congruence of Problem Seeking with Herbert Simon's (1956) proposition on "satisficing" complex problems and with Rittel and Webber's (1973) Wicked Problems formulations. ${ }^{6}$ Daniel Bell's (1973) The Coming of Postindustrial Society, closes the loop.

A number of other such corresponding events are depicted in Figure 2 taken from Bachman (2008). In the Two Spheres analysis, architecture's grasp of complexity is set into four encounters: Messy, Ordered, Wicked, and Natural (Bachman 2012). The parallels of postindustrial and sustainable evolution in architecture are also shown in that figure to align with the matching literature in history and systems theory... even if architecture lags somewhat conservatively behind in its adoption of mainstream scholarship.

\footnotetext{
${ }^{6}$ Also see Simon's formulation of "bounded rationality" (1957). "A Behavioral Model of Rational Choice", in Models of Man, Social and Rational: Mathematical Essays on Rational Human Behavior in a Social Setting. New York: Wiley.
} 


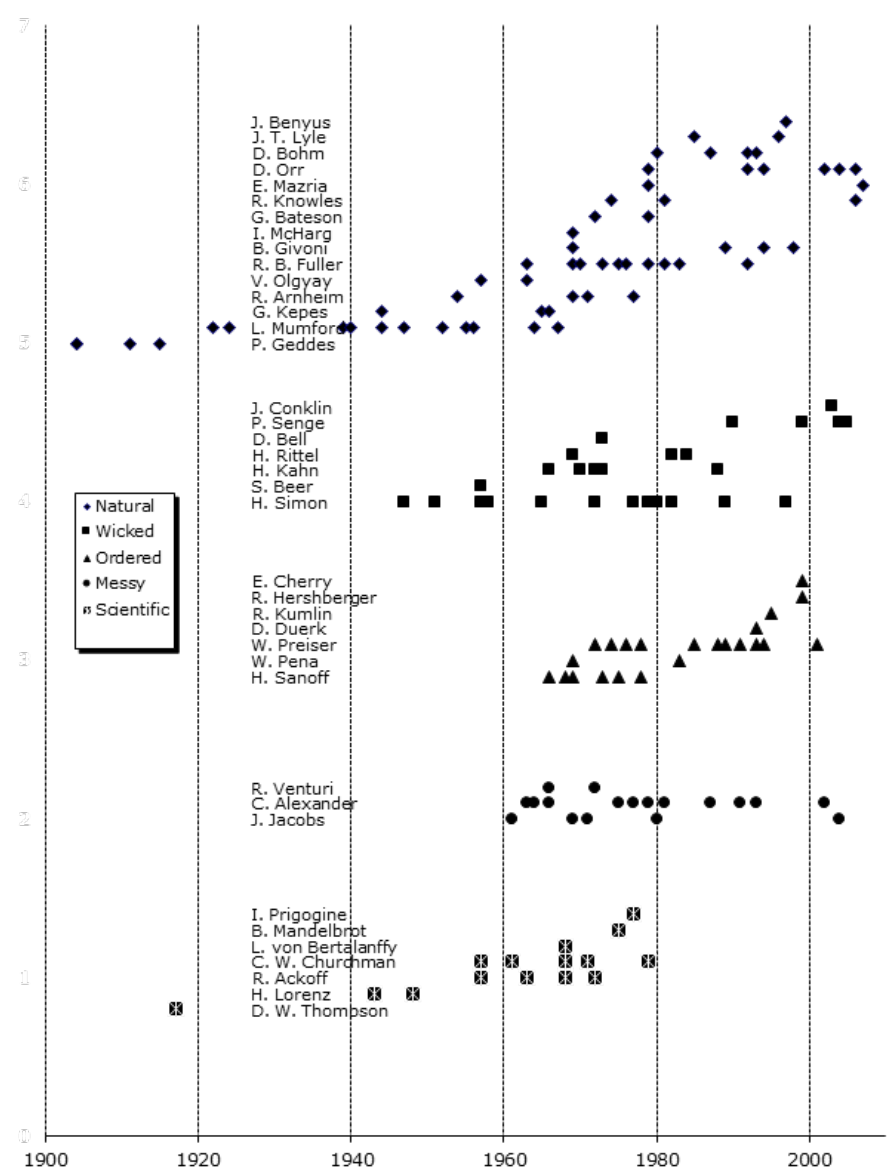

Figure 2. Timeline of Complexity Literature in Architecture and Science (from Bachman, 2008)

As stated in the introduction, where our postindustrial and sustainable evolutions intersect, there are already a large number of corresponding normative shifts in political, technical, and regulatory frameworks. And again, those normative adaptations evolved in the usual rote mechanistic ways because the old apparatus of incremental and isolated change was the only device available. Similar to the ideas in Pena's Problem Seeking and the rest of this closely related literature however; a new kind of second order skill has emerged in the sense-making that enables us to deal with such rapidly changing technology and market forces

\section{ETHICS AND AESTHETICS: ON THE AXIS OF VALUE}

"The beautiful is the symbol of moral good" (Kant 1790)

The second pair of forces are connected by an aesthetic bridge that, as discussed herein, spans across Kantian notions of the real and the perceived, or the sensible and the supersensible (i.e., the noumenal and the phenomenal). Since design is, ultimately, the act of making a better world; the activity of design is inherently tied to our sense of what is right and good. Beyond what is impressive or novel, a true design aesthetic brings forth the will of human intention and reveals a sense of purpose and distinction. In the built environment, that notion is the unity expressed by Keats' (1819) "Truth is beauty..." and also what Coleridge (1898) sees separating design from "fancy." And as Karsten Harries (1983) points out, intention and expression are what distinguishes works of architecture from arbitrariness, by which he means that a particular design will not convey "the sense that it could have easily been otherwise."

Aesthetics spans the chasm between the real and the ideal, between unmediated sublime immediacy and deliberate reflective foresight, and between understanding and appreciation. Similarly, our sense of ethical correctness and social good is connected to our aesthetic values. This is where ethics and aesthetics meet. In the intentional actions of design then, both ethics and aesthetics are tied to the teleological notion of purpose. We know this to be true because design is nothing if not the translation of ideal aspiration into real function. At some level then, the real-to-ideal connective aspects of aesthetic appreciation also make meta-connections between aesthetics and ethics.

Consider also that a project in the built environment always serves four different client bases and often it is difficult to distinguish among or between them: owner, user, public, and critic. Returning to the axis of history then, both postindustrial and sustainable forces demand ethical attention to the user who occupies and uses the facility (building, landscape, neighborhood...) and the public who share their civic community with the project's presence, be it harmonious or intrusive, congruous or discordant. The aspect of sustainable equity is particularly important here and invokes the altruistic responsibility of built environment professionals to "do good."

Equity also connects to the sense of aesthetic beauty when it satisfies our aspiration of an ideal way of life. Aspiration, as is explicit in the re-definition of sustainability in the premise of this paper, is explored deeply in Harries' Nonarbitrary Architecture in seeking out the designer's motives toward built form (Harries 1983). Along with that "ideal way of life," Harries also elicits design aspirations based on other ideals such as defining our place in nature, to articulate what is essential, to create meaning in a meaningless world, to draw order out of chaos, and a number of other inspirations the reader may infer.

At the intersection of ethical and aesthetic concerns then, the following summary points can be made about the built environment:

1. Design is ethically based in altruistic service to society at large;

2. Design is increasingly based both on aspirational ideals and real measured outcomes;

3. Bridging from the real to the ideal is both an aspirational and aesthetic act of design; and

4. Postindustrialism and sustainability both embody new ethical and aesthetic standards. 


\section{CONCLUSION: THE COMPLEX CROSSROADS}

To say that postindustrial and sustainable evolution are linked to a crossroads shift in aesthetic and ethical principles, it has been necessary to explore the four individual forces as two historical evolutions and two value propositions. Further, to show how this dynamic presents a transformation paramount to Kuhn's (1962) depiction of paradigm shift, the contemporary crossroads nexus of the situation was overviewed.

No claim of a unique situation is possible or intended here, because intersection points of history and value are continuous junctures in society; their crossroads is a constant tumult of passage and change. But none of us are standby observers passively watching the traffic, we are all navigators out on the road. And despite the ongoing flux of activity, current conditions always dictate how we move on into the future. We must keep our eyes on the road, so to speak. And, to the main point of this entire argument, although history and value are always interacting, the built environment has never been as caught up in the matrix of progress and prosperity in the manner it is now.

The name of this crossroad is "Complexity" and that naming takes us back to Karsten Harries:

Venturi's claim that "architecture is necessarily complex and contradictory in its very inclusion of the traditional Vitruvian elements of commodity, firmness, and delight" must be taken seriously, as must its consequences. (Harries 1983, 16)

While one might take exception to a narrow view of "commodity, firmness, and delight" because it seems to exclude reference to purposeful intent; a broader interpretation of Vitruvius is certainly merited; and the three-part scheme does capture the complexity of design problem space well enough. The broader point is that the wicked complexity of problem space, operations, and solution space in design of the built environment has been established as a point of departure for almost 30 years.

Complexity is also captured in the cognitive model of aesthetics taken here from Kelso's distinction of Dynamic Patterns of the two brain hemispheres and the self-organizing, self-regulating emergent consciousness of the mind (Kelso 1999). As a model for complex systems and for the built environment, such mindfulness incorporates dynamic interaction, purposefulness, and interrelatedness, as well as cybernetic feedback, adaptation, and learning. Such characteristics are in turn directly representative of postindustrial thinking and sustainable behavior.

The three cornerstones of western civilization are, as Plato describes in The Republic, truth, beauty, and intentional good acts that purposefully advance the human condition (Diessner et al. 2008). As applied to contemporary professional activity in the built environment, those three foci correspond to ethics, aesthetics, and design, respectively. Further, Plato's three cornerstones certainly resonate with Vitruvius' three pillars, even if there is not a direct one-to-one correspondence.

This paper describes the crossroads intersection of postindustrial society and sustainable design on the historic axis, with ethics and aesthetics on the axis of value. The motivation is to provide a coherent perspective that situates these four forces in a matrix of coherent change and progress. Without such a framework of perspective, there is a real possibility that the management of postindustrial and sustainable evolutions will be treated as piecemeal technical and political problems. If we use the old and outdated industrial age thinking that got us into this predicament, we will trip over our own feet and drag ourselves down with obsolete apparatus.

Built environment professions have special responsibility for advancing the transformative forces of these historic and value vectors; and they must do so by purposeful and systemic engagement of the issues. This mandate is driven by their stewardship of the environment and their social contract with society. Given that society, as a client, is shifting from an industrial mode of mechanistic rote expertise to one of postindustrial dynamic sense-making; from simple problems to wicked ones it stands to reason that design of the built environment must recognize and engage that transformation by providing suitable facilities in which to transact the new model of production. At the same time, our macro context for design is changing from an industrial era of linear throughput to a postindustrial realization of interrelated cycles and sustainable flows; from disconnected flows to sustainably integrated ones. Here again, design is challenged to reformulate its problem space, operations, and solution space in a systemic and holistic way.

Built environment professionals must all respond by making certain that our current needs and aspirations are met without sacrificing the sustenance and dreams of future generations. The technical and regulatory resources to do so are already in place. What is lacking is the impetus of an ethic and aesthetic consciousness that binds us to longterm investment and broad-based human aspiration rather than chronic short-termism.

\section{ACKNOWLEDGMENTS}

Professors Jeffrey Jackson and Christine Bachman provided important philosophical and psychological perspectives for this paper in its formative stages. I also wish to acknowledge the support of the University of Houston, Gerald D. Hines College of Architecture, especially the ongoing collegial support of the college faculty. The topic overlay of sustainability and aesthetics discussed here also owes a great deal to my long-standing conversations with Ralph Knowles, Emeriti Professor at USC, and Prof. Mark Childs, University of New Mexico.

\section{REFERENCES}

Ackoff R. L. 1974. Redesigning the future: A systems approach to societal problems, New York: John Wiley.

Alexiou, K.; J. Johnson, and T. Zamenopoulos eds. 2009. Embracing Complexity in Design, London: Routledge .

Aristotle. On the Generation of Animals. GA I 4, 717a15-16.

Bachman, Leonard R. 2007. Eco-Aesthetics: Bridging Architectural and Ecological Motivations, Solar 2007 National Solar Energy Conference, American Solar Energy Society, Cleveland.

Bachman, Leonard R. 2007. Post-industrial Society, Dynamic Complexity 
and the Emerging Principles of Strategic Design, Journal of ARCC, The Architecture Research Centers Consortium, Philadelphia.

Bachman, Leonard R. 2008. Architecture and the Four Encounters with Complexity, Architecture Engineering and Design Management, July.

Bachman, Leonard R. 2009 Towards a Clinical Database of Architecture, Proceedings of the ARCC/EAAE International Conference on Architectural Research, San Antonio, Texas.

Bachman, Leonard R. 2012. Cybertown: the other façade of the postindustrial city. ARCC/EAAE International Conference on Architectural Research, Milan, Italy.

Bachman, Leonard R. 2012. Two Spheres: Physical and Strategic Design in Architecture. London ; New York: Routledge.

Bachman, Leonard R. 2012. Two Spheres: Physical and Strategic Design in Architecture. London; New York: Routledge.

Bachman, Leonard R. 2013. Embracing Complexity in Architectural Learning. ASCE Centennial Conference, Corpus Christi, Texas.

Bachman, Leonard R. 2013. Four Gates to the Castle: a native framework for architectural inquiry. ARCC Annual Conference on Architectural Research, Charlotte, NC.

Bachman, Leonard R. 2013. New Professionalism: the postindustrial perspective, Invited Commentary for the special issue on New Professionalism, Building Research and Information, Summer, 2013.

Bachman, Leonard R. 2015. Postindustrial Frameworks: beginning design studies in the third age of production. NCBDS, National Conference on Beginning Design Studies. Houston, February.

Bachman, Leonard R. 2015. Scaffolding: discourse, disruption, and progress in architecture as a cultural production. ARCC Annual Conference on Architectural Research. Chicago, April 2015 forthcoming.

Bell, Daniel. 1973. The Coming of Post-Industrial Society; a Venture in Social Forecasting. New York, Basic Books.

Bell, Daniel. 1976. Welcome to the Post-Industrial Society. Physics Today. 29 no. 2: 46-49. https://doi.org/10.1063/1.3023314

Bohm, David. 1980. Wholeness and the Implicate Order. London; Boston: Routledge \& Kegan Paul.

Bordass, Bill and Lehman, Adrian. 2013. Editorial: A New Professionalism: remedy or fantasy? Building Research and Information, Vol. 41. No.1. https://doi.org/10.1080/09613218.2012.750572

Diessner, Rhett et. al. 2008. Engagement with Beauty: Appreciating Natural, Artistic, and Moral Beauty. The Journal of Psychology, 1423., $\quad 303-329 . \quad$ https://doi.org/10.3200/JRLP.142.3.303-332 PMid:18589939

Gadamer, Hans Georg, Joel Weinsheimer, and Donald G. Marshall. 2004. Truth and Method. Continuum International Publishing Group.

Gadamer, Hans-Georg. 1986. The Relevance of the Beautiful and Other Essays. Cambridge [Cambridgeshire] ; New York: Cambridge University Press.

Harries, Karsten. 1983. Thoughts on a Non-Arbitrary Architecture Karsten Harries Perspecta, Yale School of Architecture, Vol. 20. pp. 9-20.

Hill, S.; Lorenz, D.; et al., 2013 Professionalism and ethics in a changing economy. Building Research \& Information, 41:6. (p. 10). Accessed 18 December 2014 http://dx.doi.org/10.1080/09613218.2013.804778 .

Hubbard, William. 1986 Complicity and Conviction : Steps Toward an Architecture of Convention. Cambridge, MA, U.S.A. Cambridge, MA, U.S.A.: MIT Press.
Kant, Immanuel. 1790. The Critique of Judgment.

Keats, John. 1819. Ode on a Grecian Urn, published anonymously January 1920, in Annals of the Fine Arts, http://www.gutenberg.org/ files/23684/23684-h/23684-h.htm\#Page_113 accessed 22 August, 2015.

Kelso, J. A. Scott. 1999. Dynamic Patterns: The Self-Organization of Brain and Behavior. Cambridge, MA ; London: The MIT Press.

Kuhlmann, Ellen. 2013. Sociology of Professions: Towards International Context-Sensitive Approaches, South African Review of Sociology, 44:2, 7-17.

Kuhn, Thomas 1962. The Structure of Scientific Revolutions. Chicago: The University of Chicago Press.

McDonough, William \& Partners. 1992. The Hannover Principles: Design for Sustainability. Prepared for the EXPO 2000 World's Fair, Hannover, Germany.

Moore, Gordon. 1965. Cramming more components onto integrated circuits. Electronics Magazine. p. 4.

Peña, William M. and Caudill, Rowlett, Scott. (1969) Problem Seeking: New Directions in Architectural Programming. Houston: Caudill Rowlett Scott.

Popper, Karl. 1978. The Tanner Lectures on Human Values: Three Worlds. University of London. http://tannerlectures.utah.edu/_documents/ato-z/p/popper80.pdf. Accessed 30 November 2014..

Rittel, Horst W. J., Webber Melvin M.. 1973. "Dilemmas in a General Theory of Planning." Policy Sciences 4: 155-69. https://doi.org/10.1007/ BF01405730

Samuel Taylor Coleridge. 1898. Biographia Literataria, Chapter 13: Imagination. http://www.gutenberg.org/files/6081/6081-h/6081-h.htm accessed 22 August, 2015.

Scruton, Roger. 1979. The Aesthetics of Architecture. London: Methuen.

Simon, H. A. 1956. "Rational Choice and the Structure of the Environment". Psychological Review 63 2: 129-138.

Simon, H. A. 1957. "A Behavioral Model of Rational Choice", in Models of Man, Social and Rational: Mathematical Essays on Rational Human Behavior in a Social Setting. New York: Wiley.

Snyder, James C. 1984. Architectural Research. Environmental Design Series ;; v. 6; Variation: Environmental Design Series (Stroudsburg, Pa.); v. 6. New York: Van Nostrand Reinhold.

Stevens, Garry. 2002. The Favored Circle: The Social Foundations of Architectural Distinction. Cambridge, Mass.; London: The MIT Press.

Toffler, Alvin. 1970. Future Shock. New York: Random House.

Twinn, Chris 2013.: Professionalism, sustainability and the public interest: what next?, Building Research \& Information, 41:1, 123-128. https://doi.org/10.1080/09613218.2013.743306

Van der Vorst, Rita. 1998. 'Engineering, Ethics and Professionalism.' European Journal of Engineering Education, 23:2.

Venturi, Robert. 1977 Complexity and Contradiction in Architecture, 2nd ed. New York: Museum of Modern Art. 